\begin{tabular}{llll}
\hline DE DE GRUYTER & HUNGARIAN JOURNAL OF \\
\hline & INDUSTRY AND CHEMISTRY \\
Vol. 45(1) pp. 49-59 (2017) \\
hjic.mk.uni-pannon.hu \\
DOl: $10.1515 /$ hjic-2017-0008
\end{tabular}

\title{
ADAPTING THE SDEWES INDEX TO TWO HUNGARIAN CITIES
}

\author{
VIKTOR SEBEstyÉn, VIOLA SOMOgYI, ${ }^{*}$ SZANDRA SZÖKE, AND ANETT UTASI \\ Institute of Environmental Engineering, University of Pannonia, 10 Egyetem str., Veszprém, \\ H-8200, HUNGARY
}

\begin{abstract}
Numerous cities aim to mitigate their contribution to climate change and provide a liveable environment in the context of sustainable development. In order to measure these efforts, benchmarking performance would be a good solution. Methods for environmental analysis have their limitations when it comes to evaluating a city and other aggregated indicators focus on certain aspects of a sustainable or liveable settlement. The SDEWES Index was used for benchmarking several cities of different sizes in terms of metrics related to energy, water and environmental systems successfully thus it was chosen to compare the performance of Veszprém and Zalaegerszeg, two environmentally conscious Hungarian county seats of roughly the same size and population. The SDEWES Index consists of 7 dimensions, namely energy consumption, industrial profile with $\mathrm{CO}_{2}$ emissions, $\mathrm{CO}_{2}$-saving measures, R\&D, renewable energy potential and utilization, water and environmental quality, and social environment and sustainability policy. Each dimension is composed of 5 indicators that provide information on sustainable development of energy, water and environmental systems in cities. Using the SDEWES Index the strengths and weaknesses of the two cities are highlighted, locating those key parameters where improvement can be achieved. Both for Veszprém and Zalaegerszeg progress could be realized concerning energy-saving measures and the proportion of green areas could be increased. To improve the method and facilitate a more comprehensive comparison of cities of differing sizes, data should be provided concerning the territory or population. Also, the definition and inclusion of a worst and best case scenario that takes into account the parameters would be advantageous in terms of a comparison. These were named 'horror' and SDEWES cities by the authors, respectively.
\end{abstract}

Keywords: SDEWES Index, Sustainability, City development, Sustainable Energy Action Plan, City sample

\section{Introduction}

Sustainability is a key issue when it comes to the development of cities. In 2014, 54\% of the world's population lived in urban areas and according to the prognosis, the proportion will be as high as $66 \%$ by 2050 [1]. While the number and population of megacities is on the rise, $43 \%$ of urban dwellers lived in settlements consisting of less than 300,000 inhabitants in 2014 (in Europe the corresponding data was 58\%) and only a modest decrease is estimated by 2030 [2].

Looking at these numbers, it is easy to notice that urbanised areas have a huge impact on achieving sustainable development. Various cities have started to address this issue and several indicators and comparisons were created to measure specific aspects of sustainable development. A few of these numerous examples are listed in this paper.

The City Development Index [3] studies the municipalities from social and governance aspects. The Global Power City Index (GPCI) has ranked 40 metropolises since 2008 [4] considering 70 individual indicators regarding the environment, liveability and

*Correspondence: somogyiv@uni-pannon.hu
R\&D among others. The Green City Index is focused on the environmental sustainability of large cities [5]. Carbon footprints of twelve metropolitan areas [6] and the San Francisco Bay Area [7] were determined. Several others are listed by López-Ruiz et al. [8] but usually smaller towns do not fall within the scope of these benchmarks.

Environmental analysis, on the other hand, facilitates the evaluation of the impacts of human activities (different actions, projects or investments) with regard to the local environment, economy and society. In this way it provides information on the status quo and helps the practical implementation of sustainable development by focusing attention on the points to be improved [9]. Several methods have been developed to carry out the procedure: checklists [10], the matrix technique [11], the network approach [12], GIS-based methods [13] and quantitative methods [14] may be used to evaluate environmental impacts. Aggregating methods such as the Global Pollution Index $\left(\mathrm{I}_{\mathrm{PG}}\right)$ [15] may be suitable up to a point in providing a comprehensive sustainability analysis as they are only based on immission values. Several multiple-criteria decision-making (MCDM) techniques designed to assist with decision-making, e.g. the Analytic Hierarchy Process (AHP) [16] or the Technique for Order Preference by Similarity to Ideal Solution systems (TOPSIS) [17] combined with Simple 
Additive Weighting (SAW) [18], can be used as well [19]. These hierarchical methods (TOPSIS, SAW and AHP) rank the examined parameters which may be useful when deciding between options of individual investments but are problematic in terms of adapting them to the decision-making process with regard to development strategies of the settlements. The Sustainable Development of Energy, Water and Environment Systems (SDEWES) City Sustainability Index was developed to overcome the disadvantages and limitations of other measures with regard to benchmarking the performance of cities in terms of energy, water and environment systems. So far a list of 58 cities assessed by the SDEWES Index can be accessed online on the SDEWES Centre homepage [20]. Also, articles concerning the benchmarking of 12 South East European cities (such as Athens and Belgrade) [21], 22 Mediterranean port cities (e.g. Barcelona and Venice) [22], and a further 18 South East European cities (including Budapest and Pécs) [23] were published, and the inventory will no doubt be expanded upon in the near future.

In this paper two cities were evaluated by using the composite SDEWES Index and to test the method itself. Veszprém and Zalaegerszeg are two Hungarian county seats of roughly the same size and population, both are environmentally conscious, and are aiming to become environmentally friendly, liveable and sustainable cities.

Veszprém is near Lake Balaton with a population of around sixty-two thousand people and and a surface area of $126.9 \mathrm{~km}^{2}$. The city has won the Climate Star award $^{\dagger}$ [24] and aims to become an eco-city. In its Energy Strategy [25] the following objectives were set by 2026 :

- $20 \%$ of the energy demand should be satisfied by renewable energy resources while the energy renovation of public and residential buildings should be $70 \%$ complete resulting in a reduction in greenhouse gas (GHG) emissions of $25 \%$;

- $\quad 35 \%$ of transportation has to be conducted by means of public transport with environmentally friendly vehicles that are less than 10 years old and $10 \%$ of the vehicle-kilometres should be undertaken by bicycles;

- increasing the proportion of green areas to 25 $\mathrm{m}^{2} /$ capita and $60 \%$ of rainwater should be reused in some way.

Zalaegerszeg is situated in the west of the country and consists of sixty-two thousand inhabitants and a surface area of $100 \mathrm{~km}^{2}$. Since the millennium its urban development strategies have focused on becoming a "Sustainable City". In the strategy formulated in 2014

$\dagger$ The Climate Star award was founded by the Climate Alliance with the aim of demonstrating how climate protection initiatives can be implemented from the grass roots up [24]. Cities with initiatives in the fields of sustainable energy, mobility, consumption, urban and regional development, and citizen involvement may apply for the call in four categories.
[26] a major goal was to improve energy efficiency by $20 \%$ while producing more than $20 \%$ of its energy using local renewable resources by 2030 . This would result in a reduction of $36 \%$ in terms of energy-related costs. Taking 2005 as a base the GHG emissions should be reduced by $20 \%$ by 2030 while the particle pollution $\mathrm{PM}_{10}$ is planned to be mitigated by $10 \%$ by 2023 . Besides achieving these indicators, the city council aims to create and strengthen its image of being an environmentally conscious, modern and sustainable green city.

\section{Experimental}

The SDEWES Index consists of 7 dimensions and 35 main indicators (Table 1). The indicators of each dimension are explained in detail in Ref. [21]; only those that need further clarification or some sort of adjustment due to problems concerning the access of data are highlighted in this paper.

The data for each indicator were normalised according to the Min-Max method [27]. Depending on whether the lower or higher values are more desirable, either Eq. (1) or (2) is used [21-22]. An example of the first case, i.e. when lower values are favourable, would be $\mathrm{CO}_{2}$ emissions, while the normalised data for the number of local universities would be calculated by Eq. (2). Since the leader $\left(i_{x, y}\left(C_{j}\right)=\max \left(i_{x, y}\right)\right)$ equals 1 and the laggard $\left(i_{x, y}\left(C_{j}\right)=\min \left(i_{x, y}\right)\right) 0$, if only two cities are compared and the values are identical, the denominator would become 0 . To avoid this $I_{x, y}\left(C_{j}\right)$ should be set to 0 for such cases. Another solution would be to include further cities in the benchmark.

$$
\begin{aligned}
I_{x, y}\left(C_{j}\right) & =\frac{\left(i_{x, y}\left(c_{j}\right)-\max \left(i_{x, y}\right)\right)}{\left(\min \left(i_{x, y}\right)-\max \left(i_{x, y}\right)\right)} \\
I_{x, y}\left(C_{j}\right) & =\frac{\left(i_{x, y}\left(c_{j}\right)-\min \left(i_{x, y}\right)\right)}{\left(\max \left(i_{x, y}\right)-\min \left(i_{x, y}\right)\right)}
\end{aligned}
$$

where:

$I$ - normalised value of the indicator,

$x$-dimension number,

$y$ - indicator number within a dimension,

$C_{\mathrm{j}}-\mathrm{j}^{\text {th }}$ city,

$i$ - data input before normalization.

Value aggregation is done according to

$$
\operatorname{SDEWES}\left(C_{j}\right)=\sum_{x=1}^{7} \sum_{y=1}^{5} \alpha_{x} I_{x, y}\left(C_{j}\right)
$$

where $\sum_{x=1}^{7} \alpha_{x}=1$ and $\alpha_{x}$ is the weight of the $x^{\text {th }}$ dimension. The SDEWES Index of the $\mathrm{j}^{\text {th }}$ city is calculated by a double summation, where $\alpha_{1}$ and $\alpha_{5}$ are 0.22 since these dimensions include energy and $\mathrm{CO}_{2}$ emissions data. Other dimensions are weighed less $\left(\alpha_{x}=0.11\right)$ as they are not directly related to the sustainable energy action plan [21-22]. 
Table 1. The Dimensions and Indicators [21-23].

\begin{tabular}{|c|c|c|c|c|c|c|c|}
\hline \multicolumn{8}{|c|}{ Dimensions } \\
\hline & $\begin{array}{l}\text { D1: } \\
\text { Energy } \\
\text { Consumption } \\
\text { and Climate }\end{array}$ & $\begin{array}{l}\text { D2: } \\
\text { Penetration of } \\
\text { Energy and } \\
\mathrm{CO}_{2} \text {-Saving } \\
\text { Measures }\end{array}$ & $\begin{array}{l}\text { D3: } \\
\text { Renewable } \\
\text { Energy } \\
\text { Potential and } \\
\text { Utilization }\end{array}$ & $\begin{array}{l}\text { D4: } \\
\text { Water and } \\
\text { Environmental } \\
\text { Quality }\end{array}$ & $\begin{array}{l}\text { D5: } \\
\mathrm{CO}_{2} \\
\text { Emissions and } \\
\text { Industrial } \\
\text { Profile }\end{array}$ & $\begin{array}{l}\text { D6: } \\
\text { City Planning } \\
\text { and Social } \\
\text { Welfare }\end{array}$ & $\begin{array}{l}\text { D7: } \\
\text { R\&D, } \\
\text { Innovation } \\
\text { and } \\
\text { Sustainability } \\
\text { Policy }\end{array}$ \\
\hline \multirow{5}{*}{ 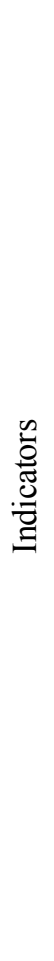 } & $\begin{array}{l}\text { Energy } \\
\text { consumption } \\
\text { of buildings } \\
\text { [MWh] }\end{array}$ & $\begin{array}{l}\text { Sustainable } \\
\text { Energy } \\
\text { Action Plan } \\
\text { (SEAP) }\end{array}$ & $\begin{array}{l}\text { Solar energy } \\
\text { potential } \\
{\left[\mathrm{Wh} / \mathrm{m}^{2} / \text { day }\right]}\end{array}$ & 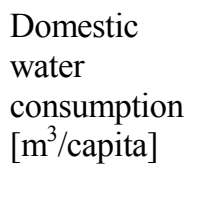 & $\begin{array}{l}\mathrm{CO}_{2} \text { emission } \\
\text { of buildings } \\
{\left[\mathrm{t} \mathrm{CO}_{2}\right]}\end{array}$ & $\begin{array}{l}\text { Price of a } \\
\text { public } \\
\text { transport } \\
\text { ticket } \\
\text { [EUR] }\end{array}$ & $\begin{array}{l}\text { R\&D and } \\
\text { innovation } \\
\text { policy } \\
\text { orientation }\end{array}$ \\
\hline & $\begin{array}{l}\text { Energy } \\
\text { consumption } \\
\text { of transport } \\
\text { [MWh] }\end{array}$ & $\begin{array}{l}\text { Combined } \\
\text { heat and } \\
\text { power-based } \\
\text { district }(\mathrm{H} / \mathrm{C})\end{array}$ & $\begin{array}{l}\text { Wind energy } \\
\text { potential } \\
{[\mathrm{m} / \mathrm{s}]}\end{array}$ & $\begin{array}{l}\text { Water quality } \\
\text { index } \\
{[/ 100]}\end{array}$ & $\begin{array}{l}\mathrm{CO}_{2} \\
\text { emissions of } \\
\text { transport } \\
{\left[\mathrm{tCO}_{2}\right]}\end{array}$ & $\begin{array}{l}\text { Urban form } \\
\text { and protected } \\
\text { sites }\end{array}$ & $\begin{array}{l}\text { National } \\
\text { patents in } \\
\text { clean } \\
\text { technologies }\end{array}$ \\
\hline & $\begin{array}{l}\text { Total energy } \\
\text { consumption } \\
\text { per capita } \\
\text { [MWh/capita] }\end{array}$ & $\begin{array}{l}\text { Energy } \\
\text { savings in } \\
\text { end-usage } \\
\text { (buildings) }\end{array}$ & $\begin{array}{l}\text { Geothermal } \\
\text { energy } \\
\text { potential } \\
{\left[\mathrm{mW} / \mathrm{m}^{2}\right]}\end{array}$ & $\begin{array}{l}\text { Annual mean } \\
\mathrm{PM}_{10} \\
\text { concentration } \\
{\left[\mu \mathrm{g} / \mathrm{m}^{3}\right]}\end{array}$ & $\begin{array}{l}\text { Average } \mathrm{CO}_{2} \\
\text { intensity } \\
{\left[\mathrm{t} \mathrm{CO}_{2} / \mathrm{MWh}\right]}\end{array}$ & $\begin{array}{l}\text { GDP per } \\
\text { capita } \\
\text { [PPP\$ } \\
\text { national] }\end{array}$ & $\begin{array}{l}\text { Local } \\
\text { public/private } \\
\text { universities }\end{array}$ \\
\hline & $\begin{array}{l}\text { Heating } \\
\text { Degree Days } \\
(\text { HDD) } \\
{\left[\text { day }{ }^{\circ} \mathrm{C}\right]}\end{array}$ & $\begin{array}{l}\text { Density of the } \\
\text { public } \\
\text { transport } \\
\text { network }\end{array}$ & $\begin{array}{l}\text { Renewable } \\
\text { energy usage } \\
\text { for electricity } \\
{[\%]}\end{array}$ & $\begin{array}{l}\text { Ecological } \\
\text { footprint } \\
\text { [gha/capita] }\end{array}$ & $\begin{array}{l}\text { Number of } \\
\mathrm{CO}_{2} \text {-intense } \\
\text { industries }\end{array}$ & $\begin{array}{l}\text { Inequality } \\
\text { adjusted well- } \\
\text { being (HPI) }\end{array}$ & $\begin{array}{l}\text { National } h \text { - } \\
\text { index of } \\
\text { scientific } \\
\text { publications }\end{array}$ \\
\hline & $\begin{array}{l}\text { Cooling } \\
\text { Degree Days } \\
(\mathrm{CDD}) \\
{\left[\text { day }^{\circ} \mathrm{C}\right]}\end{array}$ & $\begin{array}{l}\text { Efficient } \\
\text { public- } \\
\text { lighting } \\
\text { armatures }\end{array}$ & $\begin{array}{l}\text { Biofuel share } \\
\text { in transport } \\
{[\%]}\end{array}$ & $\begin{array}{l}\text { Biocapacity } \\
\text { [gha/capita] }\end{array}$ & $\begin{array}{l}\text { Airport } \\
\text { Carbon } \\
\text { Accreditation } \\
\text { (levels) }\end{array}$ & $\begin{array}{l}\text { Tertiary } \\
\text { education rate } \\
\text { (national) }\end{array}$ & $\begin{array}{l}\text { Reduction } \\
\text { Target for } \\
\mathrm{CO}_{2} \text { emission } \\
\text { reduction } \\
(2020)\end{array}$ \\
\hline
\end{tabular}

\subsection{Data of Veszprém and Zalaegerszeg}

As of October 2017, neither of the cities are signatories of the Covenant of Mayors movement, therefore, alternative sources of data had to be found. Besides the sources suggested by the developer of the index, the energy and integrated city development strategies were used to retrieve data. Necessary changes and the simplification of the original method is explained in detail below.

\subsubsection{Energy Consumption and Climate (D1):}

The energy consumption of buildings (municipal, residential and commercial) and transportation (public, private and the municipal vehicle fleet) are indicators on their own (Table 2) but also included in terms of the total energy use per capita [21]:

$$
\frac{E}{P\left(C_{j}\right)}=\frac{\left(\sum_{b=1}^{3} E_{b}+\sum_{t=1}^{3} E_{t}+E_{\mathrm{g}}+E_{\mathrm{d}}\right)}{P\left(C_{j}\right)}
$$

where

- $\quad E-$ total energy consumption (MWh),
- $P\left(C_{j}\right)$ - population of the $j^{\text {th }}$ city (capita),

- $\quad E_{b}$ - energy consumption of buildings (1: municipal, 2: residential and 3: commercial) (MWh),

- $\quad E_{t}$ - energy consumption of transport (1: public, 2: private and 3: municipal vehicle fleet) (MWh),

- $E_{\mathrm{g}}-$ energy consumption of public lighting (MWh),

- $E_{\mathrm{d}}-$ energy consumption of industry (MWh).

The energy consumption of transport was calculated based on the number of vehicles registered according to the energy strategies of the cities [25-26] by presuming an average mileage of $15,000 \mathrm{~km} /$ year and average consumption of $7.51 / 100 \mathrm{~km} \mathrm{[25].} \mathrm{The}$ energy content of diesel and gasoline was assumed to be $10.83 \mathrm{kWh} / 1$ and $8.89 \mathrm{kWh} / \mathrm{l}$, respectively. Data for commercial buildings are only included in the total energy consumption indicator as the consumption of the service sector and industries was not collected separately by the cities. As for the municipal vehicle fleet, due to a lack of data for Veszprém, this had to be neglected for both towns. It has to be noted that the data for Veszprém were from between 2007 and 2009 as stated in the strategy while for Zalaegerszeg information 
Table 2. The data of Energy Consumption and Climate (D1)

\begin{tabular}{lcc}
\hline Indicator & Veszprém & Zalaegerszeg \\
\hline $\begin{array}{l}\text { Energy } \\
\text { consumption of } \\
\text { buildings [MWh] }\end{array}$ & $309,393[25]$ & $313,434[26]$ \\
$\begin{array}{l}\text { Energy } \\
\text { consumption of }\end{array}$ & $225,479[25]$ & $217,228[26]$ \\
transport (MWh] & & \\
Total energy & $19.50(61,721)$ & $11.65(59,499)$ \\
consumption & {$[25]$} & {$[26]$} \\
[MWh/capita] & & \\
(in brackets: & & \\
population) & & $2,850[28]$ \\
$\begin{array}{l}\text { Number of } \\
\text { Heating Degree }\end{array}$ & $2,890[28]$ & \\
Days (HDD) & & $1,607[28]$ \\
Number of & $1,619[28]$ & \\
Cooling Degree & & \\
Days (CDD) & & \\
\hline
\end{tabular}

could only be obtained from between 2012 and 2013. In later documents, only improvements are mentioned, newly obtained data on overall consumption is not stated. Monitoring the energy consumption of public buildings and lighting is an issue for both cities that needs to be solved.

\subsubsection{Penetration of Energy and $\mathrm{CO}_{2}$-saving Measures (D2):}

Neither of the cities have a Sustainable Energy Action Plan (SEAP) as of 2017 [31], therefore, both received zero for the first indicator (Table 3) though Veszprém is currently in the process of creating its Sustainable Energy and Climate Action Plan (SECAP). In the case of Veszprém, a cogeneration plant was recently installed [29] while there are only plans for such a system in Zalaegerszeg (though one district heating system operates using geothermal energy) [30].

Energy savings have been accomplished and are continuously implemented in both cities by renovating public buildings and installing photovoltaic systems, e.g. on the flat roofs of a grammar and primary school in Veszprém and on the Mayor's office in Zalaegerszeg (the performance of which can be accessed online from the webpage of the city). Nonetheless, there is no building with net zero $\mathrm{CO}_{2}$ emissions, that is why both cities received 1 point for the 'energy savings in endusage' indicator. The difference in size of the cities does not necessitate different types of public transport; both Zalaegerszeg and Veszprém have local bus routes that are operated by the same regional bus company. Further points could have been allocated for tram and subway lines ( 2 for existing, 1 for planned) and an extra point would have been given to the city with the longest tram/subway network [20]. LED technology is considered an efficient public lighting solution (1 point) and an
Table 3. The data of Penetration of Energy and $\mathrm{CO}_{2-}$ Saving Measures (D2)

\begin{tabular}{lcc}
\hline Indicator & Veszprém & Zalaegerszeg \\
\hline $\begin{array}{l}\text { Sustainable Energy } \\
\text { Action Plan (SEAP) }\end{array}$ & $0[31]$ & $0[31]$ \\
$\begin{array}{l}\text { Combined heat and } \\
\text { power-based district } \\
\text { heating/cooling system }\end{array}$ & $2[25]$ & $1[26]$ \\
$\begin{array}{l}\text { Energy savings in end- } \\
\text { usage (buildings) }\end{array}$ & $1[25]$ & $1[26]$ \\
$\begin{array}{l}\text { Density of public } \\
\text { transport network }\end{array}$ & $1[29]$ & $1[30]$ \\
$\begin{array}{l}\text { Efficient public } \\
\text { lighting armatures }\end{array}$ & 2 & 1 \\
\hline
\end{tabular}

additional point can be gained if solar energy is used to power armatures. Recent investments were made in both cities to improve the energy efficiency of public lighting after the introduction of the cited strategies.

\subsubsection{Renewable Energy Potential and Utilization (D3):}

The renewable energy potential is highly dependent on the location, topology and geology of the area but the local government can have a strong influence on the utilisation of these resources. While regional data could be gathered for the potentials, national data [32] had to be used for the share of renewable sources in terms of electricity production and biofuel use in transport indicators because there was no reliable local information for Veszprém (Table 4). For Zalaegerszeg biogas from the regional municipal wastewater treatment plant is converted to provide the local buses with liquid fuel. Based on a presentation [33] the tanked volume is known for 2015, therefore, the biofuel utilization in terms of transportation was modified accordingly. To attain an accurate comparison the national value for 2015 was considered in the case of Veszprém.

Table 4. The data of the Renewable Energy Potential and Utilization (D3)

\begin{tabular}{lcc}
\hline Indicator & Veszprém & Zalaegerszeg \\
\hline $\begin{array}{l}\text { Solar energy potential } \\
{\left[\mathrm{Wh} / \mathrm{m}^{2} / \text { day] }\right.}\end{array}$ & $3,425[25]$ & $3,014[26]$ \\
$\begin{array}{l}\text { Wind energy potential } \\
{[\mathrm{m} / \mathrm{s}]}\end{array}$ & $4.921[34]$ & $3.505[34]$ \\
$\begin{array}{l}\text { Geothermal energy } \\
\text { potential [mW/m }]\end{array}$ & $60[35]$ & $90[35]$ \\
$\begin{array}{l}\text { Renewable energy } \\
\text { usage for electricity }\end{array}$ & $8.76[32]$ & $8.76[32]$ \\
$\begin{array}{l}\text { [\%] } \\
\text { Biofuel utilization in } \\
\text { terms of transport [\%] }\end{array}$ & $4.15[32]$ & $5.46[32-33]$ \\
\hline
\end{tabular}


Table 5. The data of Water and Environmental Quality (D4).

\begin{tabular}{|c|c|c|}
\hline Indicator & Veszprém & Zalaegerszeg \\
\hline $\begin{array}{l}\text { Domestic water } \\
\text { consumption } \\
{\left[\mathrm{m}^{3} / \text { capita] }\right.}\end{array}$ & $7[38]$ & $7[38]$ \\
\hline $\begin{array}{l}\text { Water quality } \\
\text { index [/100] }\end{array}$ & 92 [37] & 92 [37] \\
\hline $\begin{array}{l}\text { Average air } \\
\text { quality } \mathrm{PM}_{10} \\
{\left[\mu \mathrm{g} / \mathrm{m}^{3}\right]}\end{array}$ & 23.59 [39] & 29.60 [39] \\
\hline $\begin{array}{l}\text { Ecological } \\
\text { footprint [gha] }\end{array}$ & $2.9[40]$ & $2.9[40]$ \\
\hline $\begin{array}{l}\text { Biocapacity } \\
\text { [gha] }\end{array}$ & $2[40]$ & $2[40]$ \\
\hline
\end{tabular}

\subsubsection{Water and Environmental Quality (D4):}

There were no available local data for the domestic blue water footprint, ecological footprint and biocapacity, therefore, national values were applied in the calculation. Air quality is only described in terms of the $\mathrm{PM}_{10}$ concentration [20]. The water quality index was ambiguous as the articles [21-22] referred to the indicator as drinking water quality but the Water Quality Index (WATQI) refers to natural water quality [36]. The index relies on the global database of the United Nations GEMS/Water Programme and includes five indicative parameters: dissolved oxygen, $\mathrm{pH}$, conductivity, total nitrogen and total phosphorous. Unfortunately the WATQI of countries are only available for 2008 [37], from 2012 the water quality index was replaced with access to sanitation and drinking water in terms of the aggregated Environmental Performance. It has to be noted that in the case of Hungary the drinking water is supplied from underground reservoirs that are only linked indirectly to surface waterbodies while in other countries these serve as direct sources of drinking water. Thus using water quality indices for inland water bodies may be good indicators of safe access to water.

\subsubsection{Emissions and Industrial Profile (D5):}

As in the case of the first dimension the emission values of the commercial buildings and municipal vehicle fleet were unavailable, therefore, these could not be included in the calculation. Information on $\mathrm{CO}_{2}$-intense industries was gathered by going through an online company database [41]. The indicator carbon accreditation of airports became zero for both cities for different reasons: Veszprém has no airport and the one near Zalaegerszeg has no accreditation. Since the first case means no emissions while in the second case the existing emissions are not measured, the purpose of the indicator is not fully achieved. The original aim was to include the emissions of the airports in some way in the SDEWES Index as the SEAPs do not take them into consideration [21].
Table 6. The data of $\mathrm{CO}_{2}$ Emissions and Industrial Profile (D5)

\begin{tabular}{|c|c|c|}
\hline Indicator & Veszprém & Zalaegerszeg \\
\hline $\begin{array}{l}\mathrm{CO}_{2} \text { emissions of } \\
\text { buildings }\left[\mathrm{t} \mathrm{CO}_{2}\right]\end{array}$ & $87,882[25]$ & $82,579[26]$ \\
\hline $\begin{array}{l}\mathrm{CO}_{2} \text { emissions of } \\
\text { transport }\left[\mathrm{t} \mathrm{CO}_{2}\right]\end{array}$ & $71,711[25]$ & $70,282[26]$ \\
\hline $\begin{array}{l}\text { Average } \mathrm{CO}_{2} \\
\text { emissions } \\
{\left[\mathrm{t} \mathrm{CO}_{2} / \mathrm{MWh}\right]}\end{array}$ & 0.393 & 0.292 \\
\hline $\begin{array}{l}\text { Number of } \mathrm{CO}_{2} \\
\text { intense industries }\end{array}$ & $4[41]$ & $4[41]$ \\
\hline $\begin{array}{l}\text { Carbon } \\
\text { Accreditation of } \\
\text { Airport [levels] }\end{array}$ & 0 & $0[42]$ \\
\hline
\end{tabular}

\subsubsection{City Planning and Social Welfare (D6):}

Two indicators need further explanation (Table 7). The prices of public transport were introduced in Ref. [21] instead of the share of public transport in terms of total passenger kilometres [22], the latter not being accessible in all cases. The more a single ticket costs, the less likely people will choose public transport. On the other hand, easy access to public transport should result in positive externalities such as cleaner air and less traffic jams, by and large a more liveable city. The urban form and protected sites indicator is an aggregation of several factors (Table 8): compact city form (whether it is monoor polycentric), urban green areas and surrounding green corridors are evaluated.

To determine the compactness of the cities, the energy consumption of transport compared against population density was chosen, as a compact city can be described as of high population density [47] and because of the short distances cars are less likely to be used. Thus the smallest value received 3 points while the highest received 1. Urban green spaces were examined in

Table 7. The data of City Planning and Social Welfare (D6)

\begin{tabular}{lcc}
\hline Indicator & Veszprém & Zalaegerszeg \\
\hline $\begin{array}{l}\text { Price of public } \\
\text { transport ticket }\end{array}$ & $1.07[43]$ & $1.10[43]$ \\
[EUR] $(1$ EUR $=$ & & \\
310 HUF) & & 2 \\
Urban form and \\
protected sites \\
$\begin{array}{l}\text { GDP per capita } \\
\text { [PPP\$ national] }\end{array}$ & $25,068.9[44]$ & $25,068.9[44]$ \\
$\begin{array}{l}\text { Inequality adjusted } \\
\text { well-being (HPI) }\end{array}$ & $4.3[45]$ & $4.3[45]$ \\
$\begin{array}{l}\text { Tertiary education } \\
\text { rate (national) }[\%]\end{array}$ & $21[46]$ & $21[46]$ \\
\hline
\end{tabular}


Table 8. Data for Grading Urban Form and Municipal Management

\begin{tabular}{|c|c|c|}
\hline & Veszprém & Zalaegerszeg \\
\hline $\begin{array}{l}\text { Urban form and } \\
\text { protected sites }\end{array}$ & 1 & 2 \\
\hline Compact city form & 1 & 3 \\
\hline monocentric & $\mathrm{x}$ & $\mathrm{x}$ \\
\hline \multicolumn{3}{|l|}{ polycentric } \\
\hline $\begin{array}{c}\text { population density } \\
{\left[\text { capita } / \mathrm{km}^{2}\right]}\end{array}$ & 486.38 & 580.99 \\
\hline Urban green spaces & 1 & 2 \\
\hline $\begin{array}{l}\text { urban park intensity } \\
\qquad\left[\mathrm{m}^{2} / \text { capita }\right]\end{array}$ & 21 [29] & $34.6[30]$ \\
\hline Green corridors & 1 & 1 \\
\hline protected sites & $\mathrm{x}$ & $\mathrm{x}$ \\
\hline national park/Ramsar & $\mathrm{x}$ & $\mathrm{x}$ \\
\hline
\end{tabular}

comparison with the Hungarian county seats [48]: 0-30 $\mathrm{m}^{2} /$ capita: 1 point, $30-50 \mathrm{~m}^{2} /$ capita: 2 points and over 50 $\mathrm{m}^{2} /$ capita: 3 points. Green corridors were also assessed on a county basis [49] instead of using the suggested GISbased method [20]. The categories were determined from 1-3 by only taking the green corridor areas of Hungarian counties into consideration.

\subsubsection{R\&D, Innovation and Sustainability Policy (D7):}

Results for the seventh dimension are listed in Table 9. The number of public and private universities yielded an unexpected result for the two cities in question. Universities seated in the town and those where only a faculty is based there were equally counted. If only those universities that are seated in the said city were taken into consideration, Veszprém would have 2 versus 0 in Zalaegerszeg. Additional points were given if the university was listed in the Scimago Institutions Rankings [53]. The energy strategy of Veszprém envisions a $25 \% \mathrm{CO}_{2}$ emissions reduction by 2026 , the basis being 2007 [25], while Zalaegerszeg aims to achieve a $36 \%$ reduction by 2030, compared to 2012 [26]. To facilitate a comparison, goals for 2020 were calculated by linear interpolation.

\section{Results}

After processing the necessary calculations, the SDEWES Indices of both Veszprém and Zalaegerszeg were 1.54. As is clear in Fig.1, the values are integers and, except for one case (D5), Veszprém achieved better or equal results. It also has to be noted that on several occasions the difference between the data was very
Table 9. The data of the R\&D, Innovation and Sustainability Policy (D7)

\begin{tabular}{lcc}
\hline \multicolumn{1}{c}{ Indicator } & Veszprém & Zalaegerszeg \\
\hline $\begin{array}{l}\text { R\&D and innovation } \\
\text { policy orientation }\end{array}$ & $3[50]$ & $2[50]$ \\
$\begin{array}{l}\text { National patents in } \\
\text { clean technologies }\end{array}$ & $2.5[51]$ & $2.5[51]$ \\
$\begin{array}{l}\text { Number } \\
\text { public/private }\end{array}$ & $3[52-53]$ & $5[52-53]$ \\
universities (city) & & \\
$\begin{array}{l}h \text {-index of scientific } \\
\text { publications }\end{array}$ & $301[54]$ & $301[54]$ \\
$\begin{array}{l}\text { Reduction Target for } \\
\mathrm{CO}_{2} \text { Emissions (2020) } \\
{[\%]}\end{array}$ & $18[25]$ & $16[26]$ \\
\hline
\end{tabular}

small. Still, the better city was awarded with 1 and the worse value with zero in the normalisation process.

In order to eliminate this problem, a third city was included in the benchmark. Ohrid was chosen as the size of this historical Macedonian town is similar to the other two and all data were available from Kilkis [21]. Also, this was the only city in this comparison that had no SEAP. As an alternative solution the 'average South East European (SEE) city' from the same article was included to put the two Hungarian cities to the test to see where they would be in the ranking of the SEE cities of that sample.

The inclusion of these two examples changed the order of the cities (Table 10). While the results of both Veszprém and Zalaegerszeg improved, Zalaegerszeg gained more from the inclusion of another city from a different country in the benchmark. The reason for the improvement of the indices is that in several cases the national data had to be included in the calculation and hence, the indicator became 0 .

While both Veszprém and Zalaegerszeg gained points from increasing the sample size, the accumulated increase was larger for Zalaegerszeg (10.03 compared to 8.12). The arrows show in which direction the indicators changed. In the case of Veszprém, data for D3 and D6 decreased but not significantly, for Zalaegerszeg there was no change in D3 and only a slight decline in D5. The SDEWES Index results are similar, the difference between the highest and lowest values is 0.37 . Nonetheless, heterogeneity exists with regard to the individual indicators. Results for each dimension are visualised in Fig.2.

Both Hungarian towns performed well concerning D1 (energy consumption and climate), D4 (water and environmental quality) and D7 (R\&D, innovation and sustainability policy), while there is room for improvement in the fields of $\mathrm{CO}_{2}$-saving measures and city planning. The average SEE city, on the other hand, possesses lower values regarding energy consumption and environmental and water quality. 


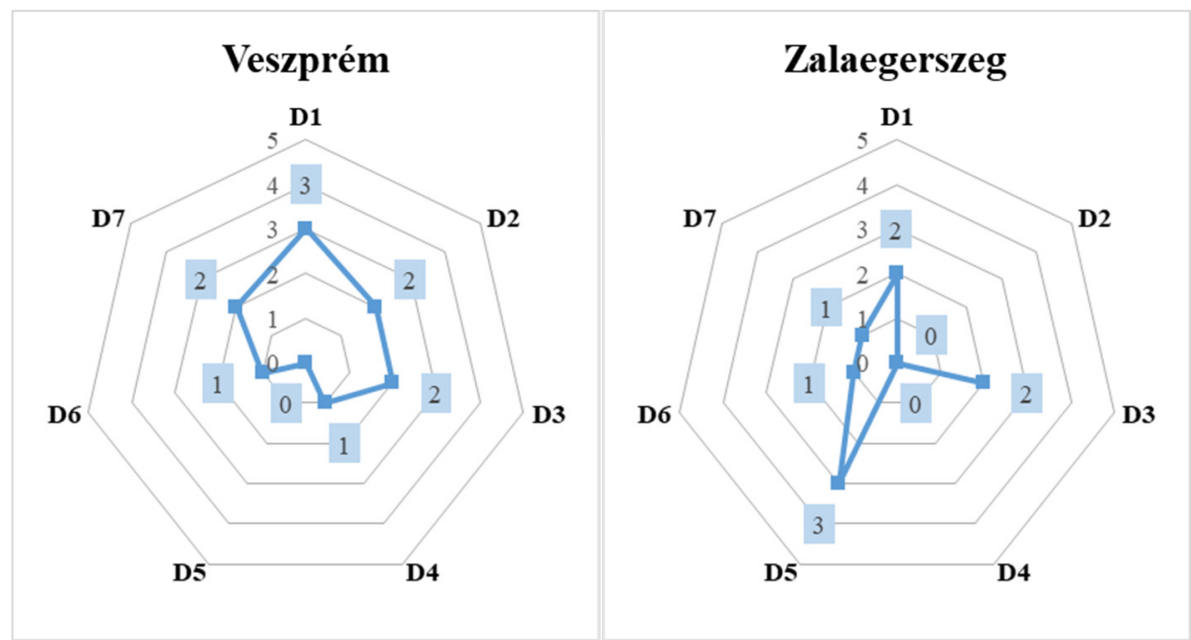

Figure 1. Results of the first comparison on radar charts.

\section{Conclusion}

The process of gathering data revealed that both Veszprém and Zalaegerszeg need to collect and measure data related to energy efficiency and other indicators of sustainable development more precisely. Creating a database of detailed information on energy use, $\mathrm{CO}_{2}$ emissions and use of renewable sources which is regularly updated would help to achieve the ambitious goal of becoming a sustainable city within a relatively short timespan. Also, the development of a SEAP or SECAP and becoming a member of the Covenant of Mayors would be advantageous and for which Veszprém has started taking steps.

Based on the dimensions of the SDEWES Index, Veszprém needs to improve in terms of D3 and D6. The individual indicators highlight that the energy consumption of public transport could be reduced, based on the example of Zalaegerszeg, and also utilization of renewable energy should be improved. In terms of city planning and social welfare the number and area of urban parks can be increased more easily than that of protected sites. Establishing green areas is included within the urban development strategy of the city [29], so improvements may be expected in terms of this indicator. Also, progress in developing a compact city form is anticipated based on the plans to reform the public transport system and relocate the central bus station to next to the railway station [29].

In the case of Zalaegerszeg, dimensions D2, D3 and D6 are lower. Energy-saving measures could be improved by constructing a cogeneration plant to improve the penetration of district heating, using solar panels in public lighting, and also using the wastewater heat to facilitate the full utilization of biogas as a liquid biofuel [55]. In the case of D3, the potential of solar and wind energy cannot be increased and no information concerning the local use of renewable energy resources in terms of electricity was found. As for D6 the same suggestions as in the case of Veszprém can be made to increase the values of the individual indicators. It has to

Table 10. Results of calculating the SDEWES Index

\begin{tabular}{ccccc}
\hline & Veszprém & Zalaegerszeg & Ohrid & $\begin{array}{c}\text { Average } \\
\text { SEE city }\end{array}$ \\
\hline D1 & $3.53 \uparrow$ & $3.93 \uparrow$ & 3.78 & 1.43 \\
D2 & $2.45 \uparrow$ & $0.95 \uparrow$ & 2.00 & 3.50 \\
D3 & $1.99 \downarrow$ & $2.00-$ & 1.60 & 3.12 \\
D4 & $4.17 \uparrow$ & $3.43 \uparrow$ & 2.45 & 1.16 \\
D5 & $2.28 \uparrow$ & $2.79 \downarrow$ & 3.00 & 2.45 \\
D6 & $0.98 \downarrow$ & $1.95 \uparrow$ & 4.00 & 3.65 \\
D7 & $3.72 \uparrow$ & $3.97 \uparrow$ & 1.08 & 1.75 \\
\hline SDEWES & $\mathbf{2 . 7 4} \uparrow$ & $\mathbf{2 . 8 3} \uparrow$ & $\mathbf{2 . 7 1}$ & $\mathbf{2 . 4 7}$ \\
\hline
\end{tabular}




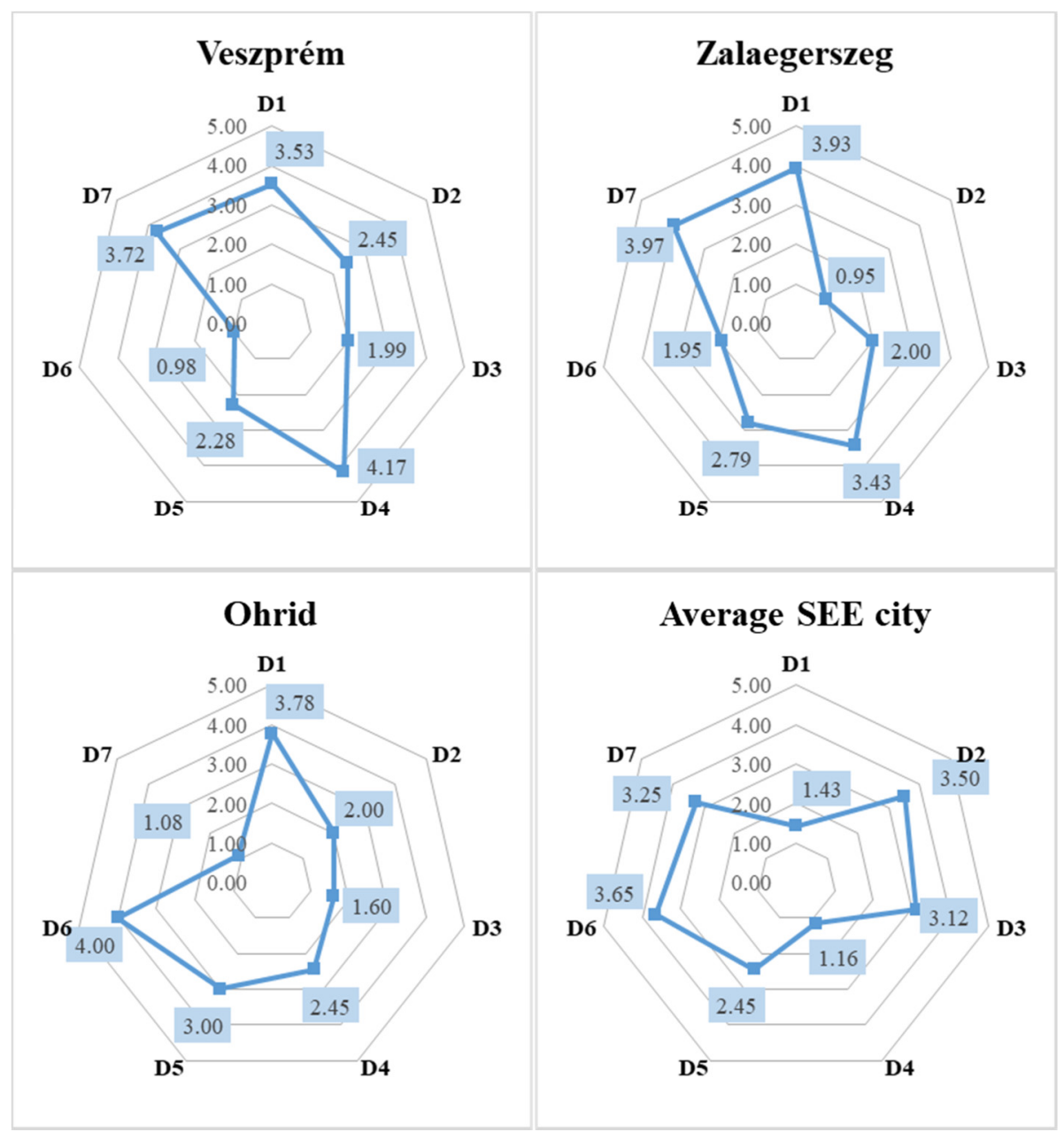

Figure 2. Results of the second comparison on radar charts.

be pointed out though that the use of the ticket price for public transport resulted in an unjust outcome: since in Ohrid there is no means of local public transport, this indicator became zero, which could also mean that transportation is free. Therefore, Ohrid will always receive the highest value in terms of the process of normalisation as long as there are no local buses in the city. In terms of the process of evaluating the two Hungarian county seats, the benchmarking method was assessed as well. Without a doubt, the SDEWES Index has its benefits. It uses environmental, economic and social indicators, gives credit to $\mathrm{CO}_{2}$ reduction goals and also considers the possible use of renewable resources. Also, human resources are included presuming that higher education and research and development seek to achieve sustainability.

On the other hand, the authors identified some drawbacks, too. The first and the fifth dimensions both focus on energy consumption and CO2 emissions. Since these data strongly correlate with each other, the inclusion of both measures leads to redundancy. Also, these two dimensions are weighed more than the others, therefore, energy-related information outweighs other aspects of sustainability. Furthermore, some of the parameters favour smaller cities over larger ones and vice versa. For example if the absolute values of energy consumption of a small city and a capital are compared, the small city will undoubtedly achieve a better result.

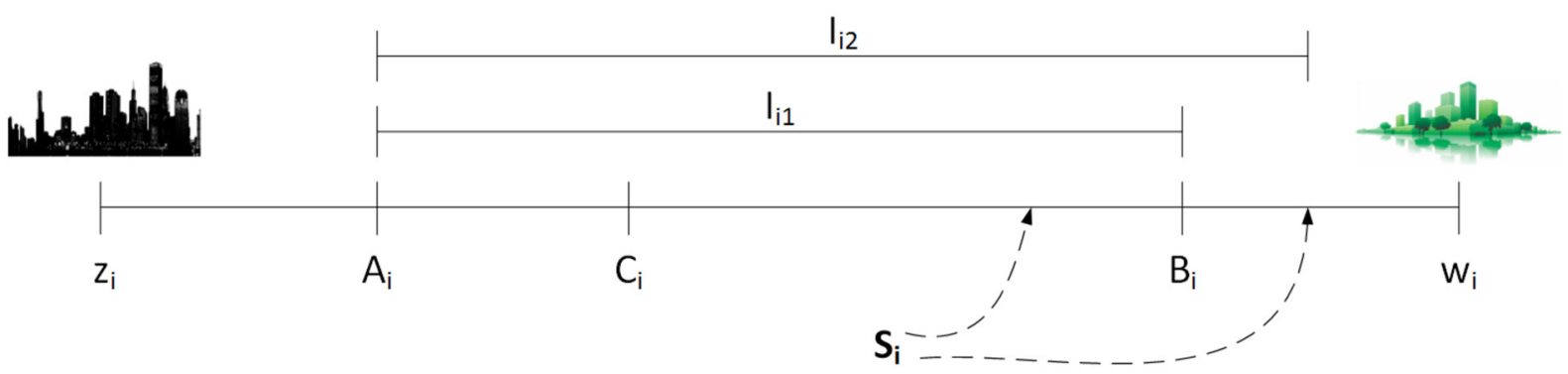

Figure 3. The evaluation intervals of SDEWES Index indicators 
An example of the opposite would be a city with an accredited airport (ACA 3) as opposed to a town with no airport (small towns do not always have airports). Similarly in a capital, where subway and tram lines are at one's disposal, the density of the public transport network would be high while it would be uneconomical to have trams in a smaller town where the bus lines are sufficient. To overcome the problem of favouring results of cities of different sizes, using data which is proportional to area or population is suggested wherever possible.

Another problem was that the scoring of the qualitative indicators such as the urban form and protected sites was not always clear. If the SDEWES Index is to be used widely then these calculations have to be made transparently and be well documented.

Due to the nature of the Min-Max method, small differences may be magnified and large differences may diminish. Also, as the index requires certain data that can only be obtained on a national level, the comparison between cities in the same country is somewhat limited. A solution to this problem may be to include towns from different countries and to choose a range (by including more than two cities) in such a way that provides balanced scales in terms of the indicators.

While normalisation facilitates the inclusion of values on different scales, the Min-Max method makes it difficult to compare the results of two sets of cities. At present, the extremes are defined by the individual parameters of the cities chosen to be included in the benchmark (Fig.3). In terms of another comparison with a different batch of cities (that can have a common set as with the previous version) the two evaluation intervals may not be equal $\left(I_{i 1} \neq I_{i 2}\right.$ since $S_{i} \in I_{i 2}$ and $\left.S_{i} \notin I_{i 1}\right)$. As the two extremities are different in the two benchmarks, the results cannot be compared to each other. In the case of extremities a change in the order might appear as was the case in this paper.

Including the average of a different batch of cities (given that the average of any parameter is not equal to that of either city) may resolve the limitations of the Min-Max method but only momentarily. Since the ranking is dynamic and changes as the cities develop, the average SDEWES Index of a previous time period will not provide relevant information with regard to the current situation concerning the sample from which the average city was created and neither on the sample of two cities one wanted to expand.

Besides the obvious solution of having a sample size of at least three cities, the authors suggest the following: two artificial sets of parameters should be created to serve as absolute extremes of the SDEWES Index. The worst case scenario is referred to as the 'horror city' and the best case scenario is named 'SDEWES city' after the Index itself.

The legend for Fig. 3 is as follows:

- $\mathrm{A}_{\mathrm{i}}, \mathrm{B}_{\mathrm{i}}, \mathrm{C}_{\mathrm{i}}$ - The measured/real indicator values of the analysed cities in the first calculation.

- $\mathrm{S}_{\mathrm{i}}-$ The measured/real indicator value of the city to be included in the second calculation.
- $\mathrm{I}_{\mathrm{i} 1}-$ The evaluation interval, when the new city's value is between the other indicator values.

- $\mathrm{I}_{\mathrm{i} 2}-$ The evaluation interval, when the new city's value falls outside of the other indicator values.

- $z_{i}-$ The theoretical minimum value of indicator i, the 'horror city'.

- $\mathrm{w}_{\mathrm{i}}$ - The theoretical maximum value of indicator $i$, the 'SDEWES city'.

To resolve this problem with regard to the evaluation intervals changing from time to time, the minimum and maximum values of each indicator must be determined in a way that the examined cities could be included in the evaluation intervals:

$$
\begin{gathered}
I_{i 1}=I_{i 2}=I_{i j} \\
S_{i} \in I_{i 2}, S_{i} \in I_{i 1} \ldots S_{i} \in I_{i j} \\
z_{i} \leq S_{i} \leq w_{i}
\end{gathered}
$$

Defining these utopian and negative examples requires careful examination of the indicators. Some parameters are dependent on the geographical location while others need to follow a realistic optimal and unfavourable alternative, for example, the tertiary education rate may be zero in the worst case scenario but it is arguable whether $100 \%$ would be favourable from the viewpoint of urban management. Further studies are needed to define the 'horror' and 'SDEWES' cities of the SDEWES benchmarking method.

\section{REFERENCES}

[1] United Nations Department of Economic and Social Affairs Population Division: World Urbanization Prospects: The 2014 Revision, Highlights. (United Nations, New York), 2014 ISBN 978-92-1151517-6

[2] United Nations Department of Economic and Social Affairs, Population Division: World Urbanization Prospects: The 2014 Revision. (United Nations, New York), 2015

[3] Global Urban Observatory: Global Urban Indicators Database. United Nations Human Settlements Programme (UN - Habitat), 2002

[4] Yamato, N.; Sasaki, K.; Hamada, Y.; Ito, K.; Wong, Y.Y.: Global Power City Index 2015, Summary. (Institute for Urban Strategies - The Mori Memorial Foundation, Tokyo, Japan), 2015

[5] Economist Intelligence Unit: European Green City Index. (Siemens AG, Munich, Germany), 2009

[6] Sovacool, B.K.; Brown, M.A.: Twelve metropolitan carbon footprints: A preliminary comparative global assessment, Energy Policy, 2010 38, 48564869 DOI: $10.1016 /$ j.proeng.2017.07.146 
[7] Christopher, J.M.; Kammen, D.M.: A Consumption-Based Greenhouse Gas Inventory of San Francisco Bay Area Neighborhoods, Cities and Counties: Prioritizing Climate Action for Different Locations, Bay Area Air Quality Management District, UC Berkeley, 2015

escholarship.org/uc/item/2sn7m83z, Accessed: $15^{\text {th }}$ August 2016.

[8] López-Ruiz, V.R.; Alfaro-Navarro, J.L.; NevadoPena, D.: Knowledge-city index construction: An intellectual capital perspective, Expert Syst. Appl., 2014 41, 5560-5572 DOI: 10.1016/j.eswa.2014.02.007

[9] Toro, J.; Requena, I.; Duarte, O.; Zamorano, M.: A qualitative method proposal to improve environmental impact assessment, Environ. Impact Assess. Rev., 2013 43, 9-20

DOI: 10.1016/j.eiar.2013.04.004

[10]Eccleston, C.H.: The EIS Book: Managing and Preparing Environmental Impact Statements. (CRC Press), 2013 ISBN 9781466583641

[11]Canter, L.W.: Environmental impact assessment, second edition. (McGraw-Hill, Inc., USA), 1996 ISBN 978-0071141031

[12] Öberg, C.; Huge-Brodin, M.; Björklund, M.: Applying a network level in environmental impact assessments, J. Bus. Res., 2012 65, 247-255 DOI: 10.1016/j.jbusres.2011.05.026

[13] Speizer, F.; Magyar, I.; Enisz, K.: Municipal environmental-monitoring system, Hung. J. Ind. Chem., 2010 38(1), 63-66

[14]Utasi, A.; Yuzhakova, T.; Sebestyén, V.; Németh, J.; Robu, B.; Rédey, Á.; Lakó, J.; Fráter, T.; Ráduly, I.; Ráduly, L.; Popita, G.: Advanced Quantitative Environmental Impact Assessment Method, Environ. Eng. Manag. J., 2013 12, 305-310

[15] Shaid, A.: Methodological Limitations of Determining Global Pollution Index as a Tool for Environmental Impact Assessment and a Proposed Extension, Environment and Ecology Research, 2014 2, 240-247 DOI: 10.13189/eer.2014.020603

[16] Saaty, R.W.: The analytic hierarchy process - what it is and how it is used, Math. Modelling, 1987 9(3), 161-176 DOI: 10.1016/0270-0255(87)90473-8

[17]Ching-Lai, H.; Kwangsun, Y.: Multiple Attribute Decision Making - Methods and Applications: A State-of-the-Art Survey. (Springer-Verlag, Berlin, Heidelberg), 1981 ISBN 978-3-642-48318-9

[18] MacCrimon, K.R.: Decision Marking Among Multiple-Attribute Alternatives: a Survey and Consolidated Approach RAND memorandum. (The Rand Corporation, Santa Monica, California), 1968

[19] Herva, M.; Roca, E.: Review of combined approaches and multi-criteria analysis for corporate environmental evaluation, J. Clean. Prod., 2013 39, 355-371 DOI: 10.1016/j.jclepro.2012.07.058

[20] SDEWES Index [Online] www.sdewes.org/sdewes_index.php, Accessed: $23^{\text {rd }}$ October 2017.

[21]Kılkış, Ş.: Sustainable development of energy, water and environment systems index for Southeast European cities, J. Clean. Prod., 2016 130, 222234 DOI: 10.1016/j.jclepro.2015.07.121
[22] Kılkış, Ş.: Composite index for benchmarking local energy systems of Mediterranean port cities, Energy, 2015 92, 622-638

DOI: 10.1016/j.energy.2015.06.093

[23]Kılkış, Ş.: Benchmarking South East European Cities with the Sustainable Development of Energy, Water and Environment Systems Index, J. Sustain. Dev. Energy Water Environ. Syst., In Press, 2017 DOI: 10.13044/j.sdewes.d5.0179

[24]Holler, A.; Mader-Hirt, D.I.L. Eds.: Climate Star 2012, The European Award for Local Climate Protection Initiatives. (Land Niederösterreich, Gruppe Raumordnung, Umwelt und Verkehr, St. Pölten, Austria), 2012

old.klimabuendnis.org/fileadmin/inhalte/dokumente/20 12/Readme_ClimateStar2012_en.pdf, Accessed: $14^{\text {th }}$ February $2 \overline{0} 16$.

[25]Energy Strategy of Veszprém for 2010-2025 (Veszprém Megyei Jogú Város energetikai stratégiája 2010-2025, in Hungarian), Veszprém, 2011

[26]Zalaegerszeg - Ecocity, Renewable Energy Strategy (Zalaegerszeg - Ökováros, Megújuló Energia Stratégia, in Hungarian), Zalaegerszeg, 2014

[27] OECD-JRC, Handbook on Constructing Composite Indicators: Methodology and User Guide. (OECD, Paris), 2008 ISBN 978-92-64-04345-9

[28] Degree Days, [Online]. www.degreedays.net/, Accessed: $3^{\text {rd }}$ April 2016.

[29] Integrated urban development strategy of Veszprém (Veszprém Megyei Jogú Város integrált településfejlesztési stratégia, in Hungarian), Veszprém, 2014

[30] Integrated urban development strategy of Zalaegerszeg (Zalaegerszeg Megyei Jogú Város integrált településfejlesztési stratégia 2014-2020, in Hungarian), Zalaegerszeg, 2014

[31] Covenant of Mayors for Climate \& Energy, [Online]. ww.covenantofmayors.eu/actions/sustainableenergy-actionplans_en.html, Accessed: $20^{\text {th }}$ November 2017

[32] International Energy Agency, [Online]. www.iea.org/statistics/statisticssearch/report/?coun try $=$ HUNGARY $=$ \&product $=$ balances, Accessed: $9^{\text {th }}$ November 2017

[33]Böcskei, Zs.: Biomethane production in Zalaegerszeg (presentation), Workshop on procedures enabling better use of the energy content of sewage and sewage sludge, Budapest, $22^{\text {nd }}$ June 2017

[34] National Renewable Energy Laboratory, Solar and Wind Energy Resource Assessment, [Online]. maps.nrel.gov/swera/. Accessed: $26^{\text {th }}$ March 2016

[35] Horváth, F.; Bada, G.; Windhoffer, G.; Csontos, L.; Dombrádi, E.; Dövényi, P.; Fodor, L.; Grenerczy, Gy.; Síkhegyi, F.; Szafián, P.; Székely, B.; Timár, G.; Tóth, L.; Tóth, T.: Atlas of the presentday geodynamics of the Pannonian basin: Euroconform maps with explanatory text (A Pannonmedence jelenkori geodinamikájának atlasza: Euro-konform térképsorozat és magyarázó, in Hungarian), Magyar Geofizika, 2006 47(4), 133-137 
[36] Carr, G.M.; Rickwood, C.J.: Water quality: Development of an Index to assess country performance. UNEP GEMS/Water Programme 1-24, 2007

[37]Esty, D.C.; Levy, M.A.; Kim, C.H.; de Sherbinin, A.; Srebotnjak, T.; Mara, V.: 2008 Environmental Performance Index, New Haven: Yale Center for Environmental Law and Policy, 2008

[38] Mekonnen, M.M.; Hoekstra, A.Y.: National water footprint accounts: The green, blue and grey water footprint of production and consumption, Value of Water Research Report, 2011 50, 1-50

[39]Hungarian Air Quality Network (Országos Légszennyezettségi Mérőhálózat, in Hungarian), Ministry of Agriculture, [Online]. www.levegominoseg.hu, Accessed: $3^{\text {rd }}$ April 2016

[40]Global Footprint Network, [Online]. www.footprintnetwork.org/en/index.php/GFN/pag e/trends/hungary/, Accessed: $28^{\text {th }}$ April 2016

[41] Company database (Cégbank, a cégadatbázis, in Hungarian), [Online]. www.cegbank.hu, Accessed: $11^{\text {th }}$ April 2016

[42] Airport carbon accreditation, [Online]. www.airportcarbonaccredited.org/airport/participa nts/europe.html, Accessed: $6^{\text {th }}$ May 2016

[43] North-west Hungary Transportation Center Ltd. (Északnyugat-magyarország Közlekedési Központ Zrt., in Hungarian), [Online]. www.enykk.hu, Accessed: $3^{\text {rd }}$ April 2016

[44] The World Bank, [Online] data.worldbank.org/indicator/NY.GDP.PCAP.PP.CD, Accessed: $4^{\text {th }}$ April 2016

[45] Abdallah, S.; Michaelson, J.; Shah, S.; Stoll, L.; Marks, N.: The Happy Planet Index 2012 Report A global index of sustainable well-being, London, 2012 ISBN 9781908506177
[46] OECD, Country Note - Education at a Glance 2013: Hungary, 2013 DOI: 10.1787/eag-2017-50-en

[47]Benton, E.; Jenks, M.; Williams, K.: The Compact City: A Sustainable Urban Form? (Routhledge), 2003 ISBN: 978-0419213000

[48]Hungarian Central Statistical Office, Statistical Yearbook of Hungary 2013 (Központi Statisztikai Hivatal, Magyar Statisztikai Évkönyv 2013, in Hungarian), Budapest, 2014

[49]Hungarian Central Statistical Office, [Online]. Available: www.ksh.hu/docs/hun/xstadat/xstadat eves/i ur00 5.html., Accessed: $28^{\text {th }}$ April 2016

[50]Hungarian Central Statistical Office, Research and development 2014: Statistical Reflections (Kutatásfejlesztés 2014 Statisztikai tükör, in Hungarian), Budapest, 2015

[51]European Patent Office, [Online]. www.epo.org/, Accessed: $3^{\text {rd }}$ April 2016

[52] Site of National Higher Education Information Centre, [Online]. www.felvi.hu, Accessed: $5^{\text {th }}$ May 2016

[53] Scimago Institutions Ranking, [Online]. http://www.scimagoir.com/webvisibility.php?ranki ngtype $=$ webvisibility\&indicator $=$ Website $\% 20$ Size $\&$ sector $=\&$ country $=$ HUN\&display $=$ table $\&$ page $=2$ \&year=2008., Accessed: $5^{\text {th }}$ May 2016

[54] Scimago Journal \& Country Rank, [Online]. http://www.scimagojr.com/countryrank.php, Accessed: $4^{\text {th }}$ April 2016

[55]Baranyák, Z.; Kontra, J.; Kovács, A.; Havas, M.; Jani, I.; Mayer, Z.; Pálfi, Sz.; Garbai, L.; Kovács, K.: Zalaegerszeg Smart City 2050, Goodwill Consulting, 2016 